中国のスギ花粉症

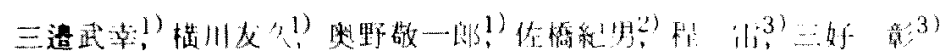

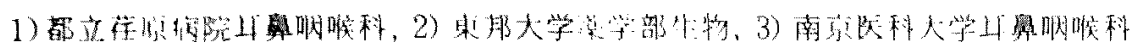

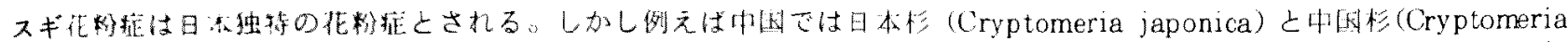

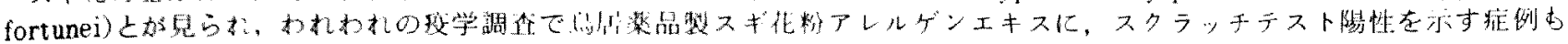
兒ら去る。

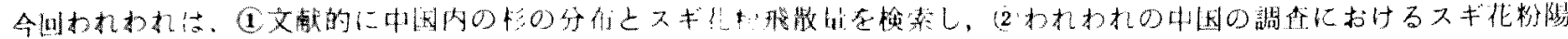

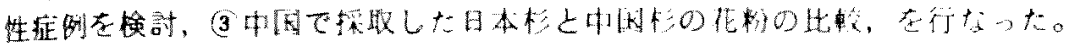

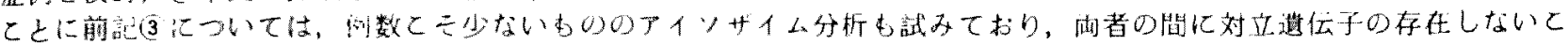

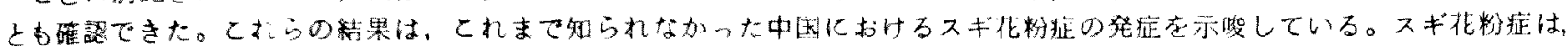

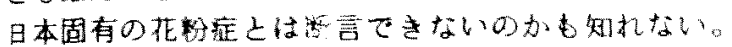

\title{
70 静岡県にお汁る睤アレルギーの抗原
}

宇传神 篤、岩崎幸司、種田 泉"

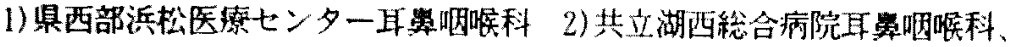

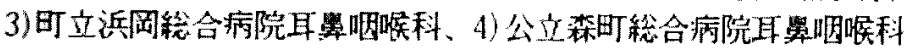

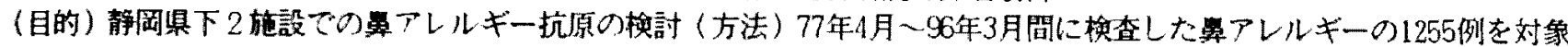
とした。抗原診断は皮内テスト48種、誘誘発テスト27種、IgE抗体测定40種を用いた。(結果) 1\%以上の)頻度を示す抗原は

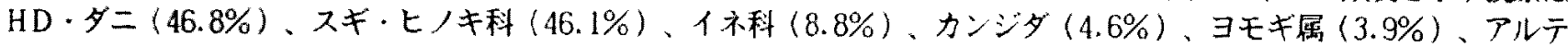

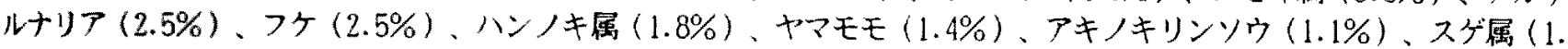
0\%)であった。HD・ダ二、イホ科、ヨモギ属、カンジダ、アルテルナリア、ハンノキ属、スゲ属的後期て增加し、スギ ・ヒノキ科、フタ、ヤマモモ、アキノキリンソウは減少した。(ま亡め)静岡市、浜松市近辺での主要抗原を明らかにした。 診原時期による達いが抗原により著明であった。かか国でこれまて報告されていない抗原もみられた。

71 トシル酸スフララタストのスギ・ヒノキ科花粉症に対する初期治療の有效性の検討

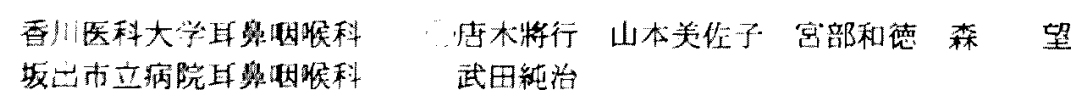

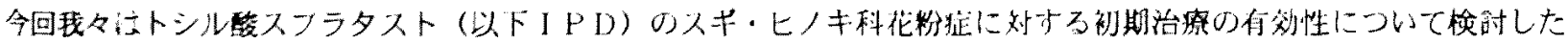

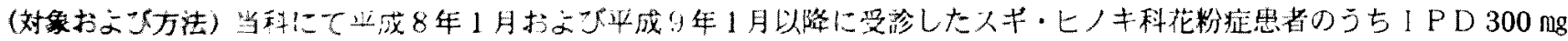

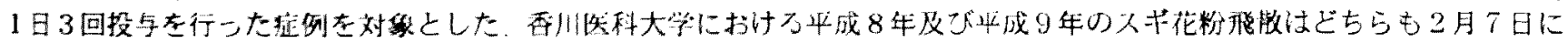

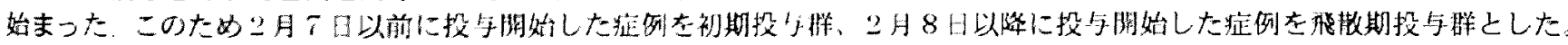

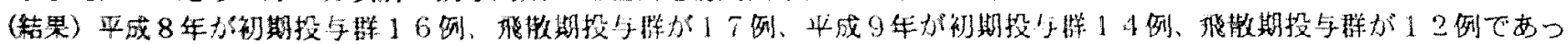

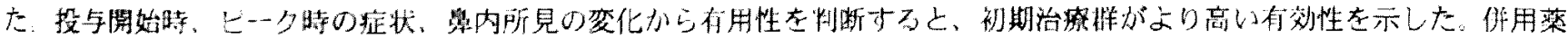

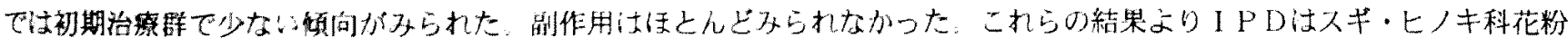

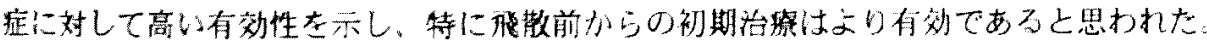

\section{7 アレルギー性鼻炎とダ二忌避剂}

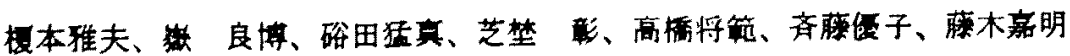 \\ 日赤和山医整センター 耳喵喉科
}

（目的）通年性アレルキー性炎の主たる原因はチりダニであり、治療の基本は除去・回避にある。このためにダ二の忌避作 用を利用するのも一つの考え方である。今回、イースタンレッドシダー（ERC）が忌避都として使えるかどうかを梌时した。

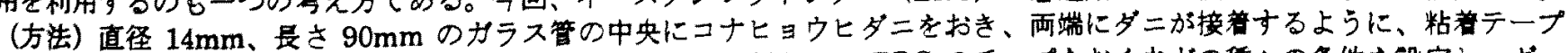

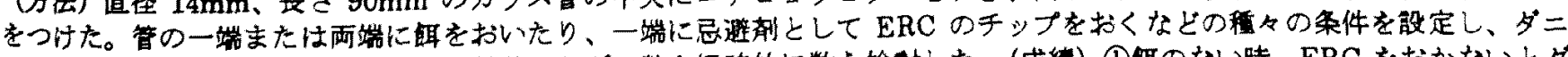

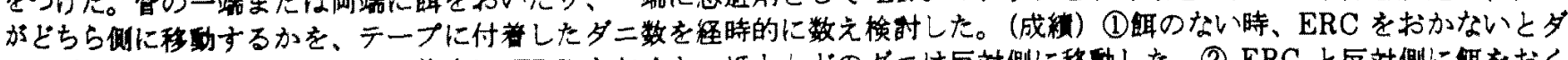

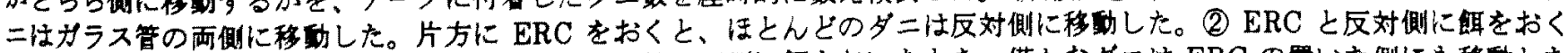

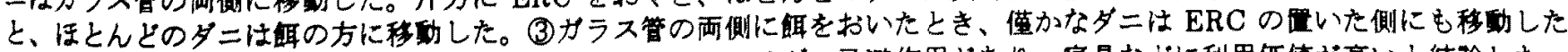
が、その多くはERCと反対側に移哩した。(結碖) ERCにはダ二忌避作用があり、安具などに利用価值が高いと結猃した。 